\title{
DETERMINAN LOYALITAS PENGGUNA APLIKASI RUANGGURU DI KOTA JAMBI DENGAN KEPUASAN KONSUMEN SEBAGAI VARIABEL MEDIASI
}

\author{
Suci Novtari Kumala Dewi ${ }^{1)}$, Johannes ${ }^{2)}$ \\ ${ }^{1)}$ Co Founder Wedding Decoration Di Temangaleri Jambi \\ ${ }^{2)}$ Program Studi Magister Manajemen FEB Universitas Jambi. \\ email: sucinovtarikd@gmail.com
}

\begin{abstract}
ABSTRAK
Penelitian ini bertujuan untuk mengungkapkan pengaruh loyalitas pengguna aplikasi bimbingan belajar online Ruangguru. Enam variabel yang dianalisis yaitu kualitas produk, harga, personal selling, e-Wom, kepuasan konsumen, dan loyalitas konsumen. Untuk itu dilakukan penelitian dengan sampel sebesar 151 responden yang diperoleh melalui perhitungan Slovin, yang diperoleh dengan menggunakan teknik tatap muka dan online. Berdasarkan pola hubungan antara determinan loyalitas terungkap bahwa harga dan personal selling adalah determinan kepuasan dan tidak terhadap loyalitas konsumen. Sementara e-wom menjadi deterimanan loyalitas konsumen, dan tidak terhadap kepuasan konsumen. Oleh karena itu, disarankan agar ruang guru meningkatkan peran personal selling dalam memanfaatkan ruang guru untuk tujuan pembelajaran secara online. Ini akan berdampak terhadap loyalitas pengguna melalui kegiatan e-Wom yang menjadi alat pemasaran tanggung terelebih di era teknologi di segala bidang.
\end{abstract}

Kata kunci : kualitas produk, harga, personal selling, E-WOM, kepuasan konsumen, loyalitas konsumen, bimbingan belajar online.

\section{ABSTRACT}

This study aims to reveal the effect of user loyalty in the Ruangguru online tutoring application. Six variables analyzed are product quality, price, personal selling, e-Wom, consumer satisfaction, and consumer loyalty. Accordingly, a study was conducted with a sample of 151 respondents obtained through Slovin's calculation, using face-to-face and online techniques. Based on the pattern of the relationship between the determinants of loyalty, it is revealed that price and personal selling are determinants of satisfaction and not consumer loyalty. Meanwhile, e-Wom is a determinant of consumer loyalty and not customer satisfaction. Therefore, it is suggested that the Ruangguru increases personal selling in utilizing the teacher's room for online learning purposes. It will impact user loyalty through e-Wom activities, which have become the overbearing marketing tool in the technological era in all fields.

Keywords: product quality, price, personal selling, E-WOM, customer satisfaction, customer loyalty, online tutoring

\section{PENDAHULUAN}

Semakin maju suatu negara maka akan semakin tinggi pula konsumsi terhadap barang dan jasa, termasuk pula jasa pendidikan. Diabad ke 21 ini sudah banyak berkembang model penyediaan jasa pendidikan atau education technology (edutech). Saat ini penyedia jasa pendidikan mengikuti platform internet sehingga mudah untuk mencapai konsumen dikarenakan semua informasi dapat diakses dengan mudah menggunakan 
internet. Saat ini Indonesia terus mengembangkan jasa pendidikan berbentuk pembelajaran elektronik atau education technology (edutech).

Saat ini telah banyak pilihan produk edutech yang menjadi ancaman yang perlu dipertimbangkan oleh Ruangguru, untuk itu dibutuhkan upaya meningkatkan loyalitas pengguna. Jika tidak, maka konsumen Ruangguru dapat berpindah ke produk dari platform lain. Menurut Wijayanto (2013) loyalitas konsumen mempunyai peran yang penting di dalam sebuah perusahaan, mempertahankan konsumen sama artinya dengan meningkatkan kinerja keuangan dan kinerja kelangsungan hidup perusahaan. Ruangguru dalam menciptakan loyalitas konsumen adalah dengan mengeluarkan produk-produk jasa dengan harga terjangkau. Mulai dari memberikan kode voucher berupa potongan harga (diskon) baik melalui iklan televisi hingga memberikan hadiah berupa souvenir bagi yang telah berlangganan sebagai wujud apresiasi perusahaan pada konsumen. Menurut Hurriyati (2005) menyatakan harga mempunyai peranan penting dalam proses pengambilan keputusan yaitu peranan alokasi dari harga adalah membantu para konsumen untuk memutuskan cara memperoleh utilitas tertinggi yang diharapkan berdasarkan kekuatan daya belinya dan untuk menunjang penjualan. Hal ini sesuai dengan penelitian terdahulu oleh Cintya et al., (2018) yang menunjukkan bahwa harga berpengaruh positif dan signifikan terhadap kepuasan pelanggan. Pelealu (2015) juga menyatakan bahwa harga berpengaruh signifikan dan positif terhadap loyalitas konsumen.

Selain itu, menjaga kualitas produk juga dapat meningkatkan kepuasan konsumen. Hudzaifah (2018) mengatakan bahwa produk adalah hal yang dapat membuat konsumen untuk melakukan pembelian terhadap suatu produk barang maupun jasa. Putri et al. (2015) dalam hal ini menunjukkan bahwa kualitas produk berpengaruh positif terhadap kepuasan konsumen. Ini juga dinyatakan oleh Rahmawati (2019) bahwa kualitas produk berpengaruh positif dan signifikan terhadap loyalitas konsumen .

Selain harga, peralatan yang digunakan pemasar untuk meningkatkan loyalitas konsumen adalah kegiatan yaitu personal selling yang senantiasa mengupayakan proses pemebelian secepatnya. Menurut Assauri S.,(2011) personal selling adalah sebagai perantara penjualan produk kepada konsumen dan untuk menyampaikan fasilitas apa saja yang akan didapatkan konsumen melalui tatap muka untuk masing-masing produk. Chantya \& Sunaryo (2015) yang meneliti mengenai personal selling yang menunjukkan bahwa personal selling berpengaruh signifikan terhadap keputusan pembelian pada pelanggan prudential. Studi lain dari Nelwan \& Mandey (2014) juga menyebutkan bahwa Personal Selling berpengaruh secara simultan terhadap kepuasan konsumen pada tour and travel di Manado.

Aplikasi Ruangguru telah menyatakan bahwa penggunanya telah mencapai lebih dari 15 juta pengguna hingga saat ini. Berdasarkan angka ini electronic word of mouth (EWOM) menjadi hal penting dalam perkembangan pemasaran digital khususnya bagi Ruangguru. Hal ini sesuai dengan penelitian terdahulu oleh Penelitian lain dari Herdiyani (2015) juga menunjukkan bahwa Electronic Word of Mouth berpengaruh signifikan terhadap kepuasan konsumen. Kepercayaan merk berpengaruh signifikan tehadap loyalitas Pelanggan. Purwanda \& Wati (2018) dalam penelitiannya mengemukakan bahwa electronic word of mouth (E-WOM) mempunyai pengaruh yang positif dan signifikan terhadap loyalitas pelanggan Lazada di Bandung timur yang berarti semakin baik E-WOM maka loyalitas pelanggan semakin tinggi. Berdasarkan pemikiran dan penjelasan inilah sehingga studi ini bermaksud menjelaskan determinan loyalitas pengguna aplikasi ruangguru di kota Jambi dengan kepuasan konsumen sebagai variabel mediasi. 


\section{TINJAUAN PUSTAKA}

Menurut Kotler (2013), kualitas produk adalah karakteristik dari suatu produk dalam kemampuannya untuk memenuhi kebutuhan-kebutuhan yang telah ditentukan dan mempunyai sifat laten. Menurut Kotler (2013) kualitas produk dapat dimasukan kedalam tujuh dimensi, yaitu:

1. Kinerja (performance) karakteristik operasi dan produk inti yang dibeli.

2. Ciri-ciri atau keistimewaan tambahan (features) yaitu karakteristik sekunder

3. Kesesuaian dengan spesifikasi (conformance to spesification)

4. Keandalan (realibiliy)

5. Daya tahan (durability)

6. Estetika (esthetica)

7. Garansi, kualitas yang dipersepsikan (perceived quality)

Harga merupakan salah satu variabel penting dalam pemasaran di mana harga dapat mempengaruhi konsumen dalam mengambil keputusan untuk membeli suatu produk karena berbagai alasan (Ferdinand, 2011). Harga adalah sejumlah nilai dipertukarkan untuk memperoleh suatu produk. Sedangkan menurut Sumarwan (2003), harga adalah atribut produk atau jasa yang paling sering digunakan oleh sebagian besar konsumen untuk mengevaluasi produk. Menurut Kotler \& Amstrong (2011) menjelaskan ada empat ukuran yang mencirikan harga, adalah: keterjangkauan harga, kesesuaian harga dengan kualitas, kesesuaian harga dengan manfaat, dan harga sesuai kemampuan atau daya beli.

Menurut Kotler \& Amstrong (2013), Personal selling is refersto "personal presentation by the firm's sales force for the purpose of making sales and building customer relationships." This tactic is most effective during certain stages of the buying process, especially when trying to build up buyer's preferences, convictions, and actions. Yang berarti bahwa Penjualan pribadi mengacu pada "presentasi pribadi oleh tenaga penjualan perusahaan untuk tujuan membuat penjualan dan membangun hubungan dengan pelanggan.

Menurut Kotler \& Keller (2017) ada enam langkah yang harus dijalankan oleh personal selling, yaitu: prospecting and Qualifiying, preaproach, presentation and demonstration, overcoming Objections, closing, dan folow Up and Maintenance.

Menurut Kotler \& Amstrong (2008), "Word of mouth communication adalah komunikasi pribadi tentang sebuah produk antara pembeli sasaran dan tetangga, temanteman, anggota keluarga dan rekannya". Hasan (2010) mendefinisikan word of mouth dalam dunia bisnis adalah tindakan konsumen memberikan informasi kepada konsumen lain dari seseorang ke orang lain (antar pribadi) non-komersial baik merek, produk maupun jasa.. Menurut Hennig-Thurau et al., (2004) bahwa Electronic Word of Mouth (EWOM) merupakan bentuk komunikasi pemasaran yang berisi tentang pernyataan positif atau negatif yang dilakukan pelanggan potensial, pelanggan maupun mantan pelanggan tentang suatu produk. Indikator electronic word of mouth menurut Sebayang (2017) yaitu:

1. Membincangkan produk di media sosial

2. Merekomendasikan produk kepada orang lain di media social

3. Menceritakan pengalaman serta merasakan produk atau jasa

Menurut Kotler \& Keller (2017) mengatakan bahwa kepuasan konsumen adalah perasaan senang atau kecewa seseorang yang muncul setelah membandingkan kinerja (hasil) produk yang dipikirkan terhadap kinerja yang diharapkan. Kotler menyatakan bahwa kepuasan pelanggan adalah tingkat perasaan seseorang setelah membandingkan kinerja atau hasil yang ia rasakan dibandingkan dengan harapannya. 
Loyalitas secara harfiah diartikan kesetiaan, yaitu kesetiaan seseorang terhadap suatu objek. Loyalitas konsumen adalah konsep multidimensi yang merupakan jenis preferensi pelanggan produk dan jasa yang terbentuk lama terkait dengan aspek kognitif, afektif dan konatif dari perilaku konsumen (Williamson, 1999). Konsumen yang loyal tetep berkomitmen melakukan pembelian pada merek yang sama, bersedia membayar dengan harga yang lebih tinggi untuk merek produk atau jasa dan selalu mempromosikan merek tersebut (Natarajan \& Sudha, 2016).

PT. Ruang Raya Indonesia (Aplikasi Ruangguru) adalah perseroan terbatas yang bergerak di bidang pendidikan nonformal. Ruangguru merupakan sebuah aplikasi penyedia layanan dan konten pendidikan berbasis teknologi yang didirikan oleh Iman Usman dan Belva Devara pada tahun 2014. Ruangguru juga telah bermitra dengan 31 pemerintah provinsi dan 326 pemerintah kota dan kabupaten di Indonesia. Hingga saat ini Ruangguru telah memiliki lebih dari 15 juta pengguna serta mengelola 300.000 guru yang menawarkan jasa di lebih dari 100 bidang pelajaran. Konten yang dimiliki aplikasi Ruangguru mencakup SD, SMP, SMA sesuai dengan kurikulum nasional dan dirancang khusus oleh pengajar terbaik dan berpengalaman. Ruangguru menyediakan sistem tata kelola pembelajaran yang dapat digunakan murid dan guru dalam mengelola kegiatan belajar dikelas secara virtual. Dilengkapi dengan ribuan bank soal yang kontennya disesuaikan dengan kurikulum yang berlaku di Indonesia, platform ujian online, video belajar beranimasi, marketplace les private, serta peralatan analisis hasil tes, dan kontenkonten pendidikan lainnya yang pengguna dapat memanfaatkannya dan bisa di akses melalui web dan aplikasi Ruangguru. Di dalam aplikasinya, Ruangguru menawarkan berbagai layanan atau fitur-fitur untuk mendukung pembelajaran, antara lain : ruangbelajar, ruangbelajar plus, ruangles, ruangles online dan ruanguji.

\section{METODE PENELITIAN}

\section{Populasi dan Sampel}

Populasi penelitian adalah seluruh pengguna aplikasi Ruangguru di Kota Jambi. Teknik pengambilan sampel adalah metode acak sederhana (simple random sampling). Berdasarkan perhitungan Slovin, ukuran sampel diambil yaitu sebanyak 151 responden.

\section{Sumber Data}

Data primer diperoleh melalui kuisioner yang dibagikan kepada responden, dimana pertanyaan kuesioner merupakan pertanyaan tertutup, kuesioner dibagian melalui google formulir. sedangkan data sekunder diperoleh dari berbagai sumber termasuk dari perusahaan yang dijadikan sampel.

\section{Analisis dan Alat Analisis Data}

Dari hasil kuesioner, data menggunakan distribusi frekuensi untuk memperoleh nilai rata-rata. Kemudian diolah menggunakan pendekatan Structural Equation Model (SEM) dengan menggunakan software Partial Least Square (PLS).

\section{Variabel Penelitian}

Variabel kualitas produk $\left(\mathrm{X}_{1}\right)$, harga $\left(\mathrm{X}_{2}\right)$, personal selling $\left(\mathrm{X}_{3}\right)$, E-WOM $\left(\mathrm{X}_{4}\right)$ dijadikan sebagai variabel independen. loyalitas konsumen (Y) dijadikan sebagai variabel dependen. Sedangkan kepuasan konsumen (M) dijadikan sebagai variabel mediasi.

\section{HASIL DAN PEMBAHASAN}

Karateristik responden

Responden berjenis kelamin perempuan adalah yang terbanyak yakni 109 reponden $(72,26 \%)$. Sedangkan sisanya adalah responden berjenis kelamin laki-laki yang berjumlah 
42 responden $(27,74 \%)$. Berdasarkan karateristik jenjang pendidikan, yang tertinggi adalah pelajar yang berasal dari SMA sebanyak 137 responden $(90,07)$, yang berasal dari SMK sebanyak 8 responden (5,3\%), yang berasal dari MA sebanyak 6 responden (4\%). Pada karakteristik status berlangganan, yang tertinggi adalah status pernah berlangganan 1 kali sebanyak 103 responden $(68,2 \%)$, pernah berlangganan lebih dari 1 kali sebanyak 23 responden $(23,8 \%)$, sedangkan status berlangganan pernag berlangganan lebih dari 1 kali sebanyak 12 responden (7,9\%). Pada karateristik berdasarkan jenis paket belajat yang digunakan, yang tertinggi adalah pengguna Ruang Belajar sebanyak 142 responden (94,67\%), kemudian Ruangbelajar Plus sebanyak 7 responden (4,67\%), dan Brain Academy Online sebanyak 1 responden $(0,66 \%)$.

\section{Nilai dan Rata-Rata Variabel Penelitian}

Penilaian responden terhadap masing-masing vaiabel penelitian kualitas produk, harga, personal seliing, E-WOM, kepuasan konsumen, dan loyalitas konsumen. Kualitas produk memiliki nilai rata-rata tertinggi sebesar 4,74; personal selling memiliki nilai ratarata sebesar 4,73; kepuasan konsumen 4,72; harga memiliki nilai rata-rata sebesar 4,67; loyalitas konsumen memiliki nilai rata-rata sebesar 4,43; dan E-WOM memiliki nilai ratarata terendah sebesar 4,24.

\section{Model Pengukuran (Outer Model)}

Uji validitas konvergen ini dinilai dari loading factor untuk tiap indikator konstruk dan nilai Average Variance Inflation Factor (AVE). Nilai loading factor harus lebih dari 0,7 untuk penelitian yang bersifat confirmatory dan antara 0,6-0,7 untuk penelitian yang bersifat exploratori. Penilaian uji validitas konvergen yang kedua dilihat dari nilai AVE masing-masing variabel. Nilai Average Variance Inflation Factor (AVE) harus lebih besar dari 0,5 .

\begin{tabular}{lll}
\multicolumn{3}{c}{ Tabel 1. Nilai AVE pada Setiap Variabel } \\
\hline No & Variabel & AVE \\
\hline 1 & Kepuasan Konsumen & 0,680 \\
2 & Harga & 0,657 \\
3 & Personal Selling & 0,717 \\
4 & E-WOM & 0,730 \\
5 & Kepuasan Konsumen & 0,746 \\
6 & Loyalitas Konsumen & 0,687 \\
\hline
\end{tabular}

Terlihat bahwa nilai AVE pada setiap konstruk kualitas produk, harga, personal selling, EWOM, kepuasan konsumen, dan loyalitas konsumen telah di atas 0,5 yang artinya keenam konstruk tersebut dikatakan valid.

Dalam PLS-SEM selain uji validitas juga perlu dilakukan pengujian reliabilitas. Uji reliabilitas bertujan untuk membuktikan akuras. Nilai Composite Reliability yang disyaratkan yakni di atas 0,7 .

Tabel 2. Nilai Composite Reliability Masing-Masing Variabel

\begin{tabular}{clc}
\hline No & \multicolumn{1}{c}{ Variabel } & Composit Reliability \\
\hline 1 & Kualitas Produk & 0,937 \\
2 & Harga & 0,920 \\
3 & Personal Selling & 0,953 \\
4 & E-WOM & 0,890 \\
5 & Kepuasan Konsumen & 0,954 \\
6 & Loyalitas Konsumen & 0,897 \\
\hline
\end{tabular}


Terlihat bahwa semua nilai composite reliability keenam konstruk telah berada di atas 0.70. Jadi dapat disimpulkan bahwa konstruk kualitas produk, harga, personal selling, EWOM, kepuasan konsumen, dan loyalitas konsumen sudah memiliki reliabilitas yang baik atau terkategori reliabel.

\section{Model Struktural (Inner Model)}

Berikut ini adalah hasil evaluasi inner model pada penelitian ini:

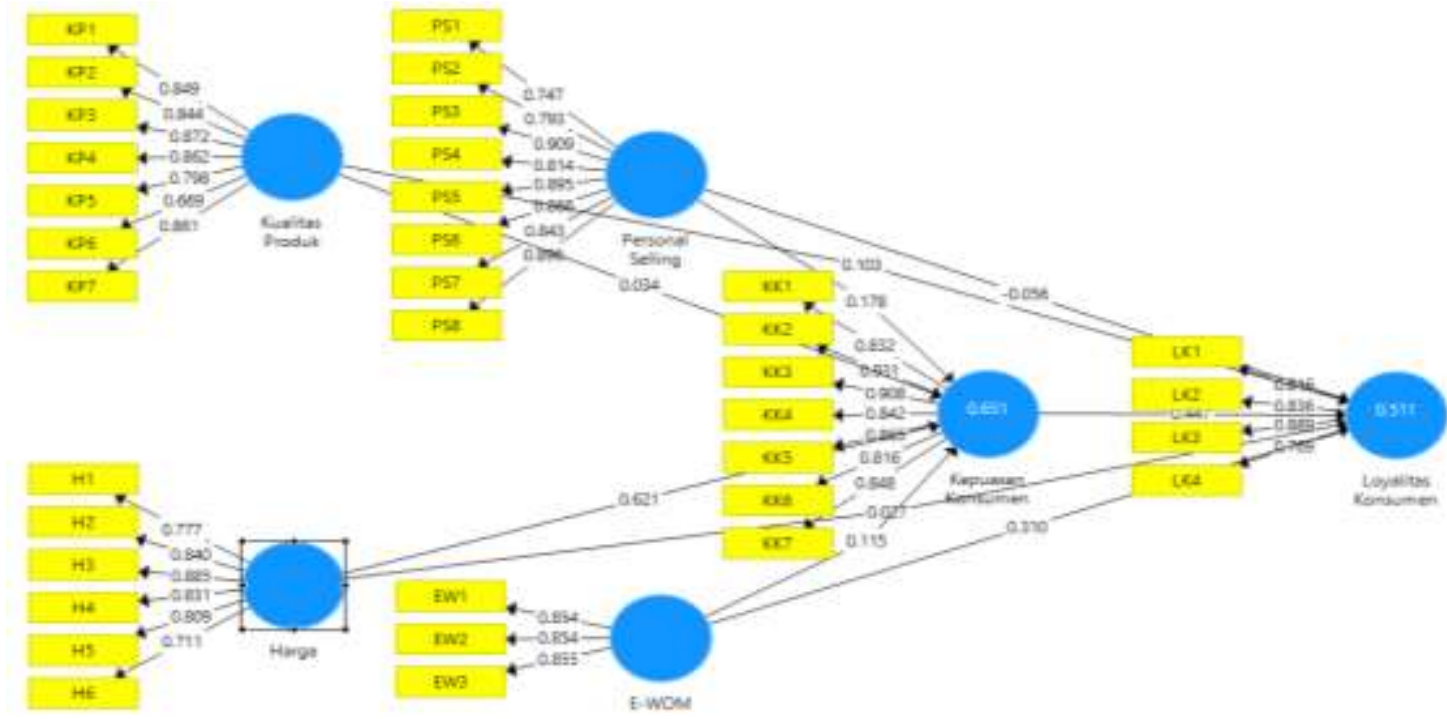

Ada dua komponen dalam penilaian model struktural (inner model) yaitu nilai $R$-Square dan Signifikansi. Nilai R-Square pada penelitian ini ialah sebagai berikut :

Tabel 3. Nilai R-Square

\begin{tabular}{clc}
\hline No & \multicolumn{1}{c}{ Variabel } & R-Square \\
\hline 1 & Kepuasan Konsumen & 0,651 \\
2 & Loyalitas Konsumen & 0,511 \\
\hline
\end{tabular}

Berdasarkan tabel 3 terlihat hasil output dari hasil analisis dengan metode bootstrapping dimana diperoleh nilai $R$-Square untuk variabel kepuasan konsumen sebesar 0.651 atau dengan kata lain variabel kepuasan konsumen dipengaruhi oleh variabel yang ada dalam model sebesar $65,1 \%$. Sedangkan Sisanya sebesar $14 \%$ dipengaruhi oleh faktor lain di luar model tersebut. Nilai $R$-Square untuk variabel loyalitas konsumen sebesar 0.511. Artinya bahwa variabel loyalitas konsumen dipengaruhi oleh variabel yang ada dalam model sebesar 51,1\%. Sedangkan Sisanya sebesar 48,9\% dipengaruhi oleh faktor lain di luar model tersebut. Sehingga berdasarkan perhitungan menunjukkan bahwa nilai R-Square termasuk moderat dan kuat karena berada pada rentang 0,511 hingga 0,651 .

Path coefficients untuk uji pengaruh langsung (dirrect effect): Melalui path coefficient dapat dilihat pengaruh antar variabel. Adapun Output hasil estimasi path coefficient seperti berikut ini : 
Tabel 4. Hasil Uji Direct Effect Determinan Loyalitas Pengguna Ruang Guru

\begin{tabular}{|c|c|c|c|c|c|c|c|}
\hline No & Variabel & $\begin{array}{c}\text { Original } \\
\text { Sample }(\mathrm{O})\end{array}$ & $\begin{array}{c}\text { Sample } \\
\text { Mean (M) }\end{array}$ & $\begin{array}{c}\text { Standar } \\
\text { Deviasi } \\
\text { (STDEV) }\end{array}$ & t Statistik & $\begin{array}{c}\mathrm{P} \\
\text { Values }\end{array}$ & Ket. \\
\hline 1 & $\begin{array}{l}\text { Kualitas Produk => Kepuasan } \\
\text { Konsumen }\end{array}$ & 0,034 & 0,037 & 0,103 & 0,325 & 0,745 & \\
\hline 2 & $\begin{array}{l}\text { Kualitas Poduk => Loyalitas } \\
\text { Konsumen }\end{array}$ & 0,103 & 0,096 & 0,076 & 1,356 & 0,176 & \\
\hline 3 & Harga $\Rightarrow>$ Kepuasan Konsumen & 0,621 & 0,621 & 0,092 & 6,720 & 0,000 & $*$ \\
\hline 4 & Harga $\Rightarrow$ Loyalitas Konsumen & 0,027 & 0,044 & 0,095 & 0,284 & 0,776 & \\
\hline 5 & $\begin{array}{l}\text { Personal Selling => Kepuasan } \\
\text { Konsumen }\end{array}$ & 0,178 & 0,173 & 0,068 & 2,634 & 0,009 & $*$ \\
\hline 6 & $\begin{array}{l}\text { Personal Selling => Loyalitas } \\
\text { Konsumen }\end{array}$ & $-0,056$ & $-0,051$ & 0,064 & 0,877 & 0,381 & . \\
\hline 7 & E-WOM => Kepuasan Konsumen & 0,115 & 0,120 & 0,072 & 1,586 & 0,113 & \\
\hline 8 & E-WOM => Loyalitas Konsumen & 0,310 & 0,312 & 0,069 & 4,531 & 0,000 & $*$ \\
\hline
\end{tabular}

Sumber: hasil olah data primer, 2021

Berdasarkan tabel diatas menunjukkan bahwa variabel harga, personal selling dan EWOM menunjukkan nilai yang signifikan, artinya harga dan personal selling memiliki pengaruh yang besar terhadap kepuasan konsumen, begitu juga dengan E-WOM terhadap loyalitas menunjukkan bahwa E-WOM memiliki pengaruh yang besar terhadap loyalitas konsumen Ruangguru.

\section{Indirect Effect}

Berikut dibawah ini merupakan hasil output estimasi total indirect effects :

Tabel 5. Hasil Uji Indirect Effect

\begin{tabular}{|c|c|c|c|c|c|c|}
\hline Variabel & $\begin{array}{l}\text { Original } \\
\text { Sample } \\
\text { (O) }\end{array}$ & $\begin{array}{l}\text { Sample } \\
\text { Mean } \\
\text { (M) }\end{array}$ & $\begin{array}{c}\text { Standar } \\
\text { Deviasi } \\
(\text { STDEV) } \\
\end{array}$ & $\begin{array}{c}\mathrm{T} \\
\text { Statistik }\end{array}$ & $\begin{array}{c}\mathrm{P} \\
\text { Values }\end{array}$ & Ket. \\
\hline $\begin{array}{l}\text { Kualitas Produk } \\
=>\text { Kepuasan Konsumen => } \\
\text { Loyalitas Konsumen }\end{array}$ & 0,015 & 0,017 & 0,046 & 0,329 & 0,743 & \\
\hline $\begin{array}{l}\text { Harga }=>\text { Kepuasan Konsumen } \Rightarrow> \\
\text { Loyalitas Konsumen }\end{array}$ & 0,278 & 0,271 & 0,069 & 4,035 & 0,000 & $*$ \\
\hline $\begin{array}{l}\text { Personal Selling } \\
=>\text { Kepuasan Konsumen => } \\
\text { Loyalitas Konsumen }\end{array}$ & 0,080 & 0,074 & 0,032 & 2,506 & 0,013 & $*$ \\
\hline $\begin{array}{l}=>\text { Kepuasan Konsumen }=> \\
\text { Loyalitas Konsumen }\end{array}$ & 0,051 & 0,052 & 0,033 & 1,571 & 0,117 & \\
\hline
\end{tabular}

Sumber: hasil pengolahan data primer, 2021

Melihat tabel di atas menunjukkan bahwa personal sellling dan harga perannya besar dalam membentuk kepuasan dan loyalitas pelanggan. Sepertinya hal ini dikarenakan produk belum lama diperkenalkan, dan kecenderungan orang belajar dengan fitur aplikasi belum sesuai. Hal ini didukung oleh penelitian sebelumnya dari Rahmawati (2019) yang menemukan bahwa harga berpengaruh positif dan signifikan terhadap kepuasan konsumen dan loyalitas konsumen Pada CV. Larissa Ready Mix Di Kabupaten Pati. Terdapat penelitian lain dari Rizan \& Anjarestu (2013) dalam penelitiannya personal selling dan kualitas produk berpengaruh signifikan terhadap kepuasan pelanggan majalah info Bekasi.Serta Purwati et al., (2020) juga menyatakan bahwa personal selling dan kualitas pelayanan berpengaruh signifikan terhadap loyalitas konsumen. 


\section{Pembahasan}

\section{Pengaruh Kualitas Produk terhadap Kepuasan Konsumen Aplikasi Ruangguru}

Berdasarkan hasil uji hipotesis awal tidak terpenuhi, sebab setelah melalui perhitungan didapatkan hasil bahwa nilai tidak signifikan, yaitu sebesar 0,745 lebih besar dari tingkat alpha 5\% (0,05) dan nilai $\mathrm{T}$ statistik sebesar 6,720 lebih besar dari 1,98761 (t-tabel), sehingga pengaruh kualitas produk terhadap kepuasan konsumen pengguna aplikasi Ruangguru, ditolak. Hasil penelitian ini didukung oleh penelitian yang dilakukan oleh Khakim (2019) bahwa tidak ada pengaruh secara signifikan antara kualitas produk terhadap kepuasan konsumen. Sejalan dengan penelitian yang juga dilakukan oleh Johannes et al., (2009) pada analisis kepuasan nasabah bank menyatakan bahwa bagi nasabah variabel promosi, produk, dan harga tidak dianggap penting. Hasil temuan ini berbeda dengan penelitian sebelumnya yang dilakukan oleh Putri et al., (2015) yang menunjukkan bahwa kualitas produk berpengaruh positif signifikan terhadap kepuasan konsumen pada pelanggan nasi rawon di kabupaten Pasuruan. Hasil penelitian lainnya dari Rahmawati (2019) juga menunjukkan bahwa kualitas produk berpengaruh positif dan signifikan terhadap kepuasan konsumen pada CV. Larissa Ready Mix Di Kabupaten Pati.

\section{Pengaruh Kualitas Produk terhadap Loyalitas Konsumen Aplikasi Ruangguru}

Berdasarkan hasil penelitian menunjukkan bahwa nilai tidak signifikan,yaitu sebesar 0,176 lebih besar dari tingkat alpha $5 \%(0,05)$ dan nilai $\mathrm{T}$ statistik sebesar 1,356 lebih kecil dari 1,98761 (t-tabel). Maka dapat disimpulkan bahwa pengaruh kualitas produk terhadap loyalitas konsumen pengguna aplikasi Ruangguru, tidak diterima. Hal ini menunjukkan bahwa kualitas produk yang dimiliki aplikasi Ruangguru tidak mempengaruhi dalam hal loyalitas konsumen. Sebaliknya hasil penelitian ini berbeda dengan beberapa penelitian lainnya dari Rahmawati (2019) dimana menunjukkan bahwa kualitas produk berpengaruh positif dan signifikan terhadap loyalitas konsumen pada CV. Larissa Ready Mix Di Kabupaten Pati. Dalam penelitian lain dari Purnama (2019) juga menunjukkan bahwa Kualitas produk dan citra merek juga berpengaruh positif signifikan pada loyalitas pelanggan pada produk Graphic Processing Unit Amd Radeon. Berdasarkan hal ini dapat diartikan bahwa kualitas produk belum tentu memiliki pengaruh terhadap loyalitas konsumen. Makna temuan ini adalah konsumen belum tentu loyal terhadap aplikasi Ruangguru jika ia mendapatkan kualitas produk yang baik. Walaupun demikian, kualitas produk tetap perlu diperhatikan dalam bisnis, karena apa yang membuat konsumen puas tetap bersumber dari apa yang diberikan penyedia jasa terhadap pelanggannya.

\section{Pengaruh Harga terhadap Kepuasan Konsumen Aplikasi Ruangguru}

Berdasarkan hasil penelitian yang telah dilakukan didapatkan bahwa nilai $\mathrm{T}$ hitung bernilai positif dan pengaruh harga terhadap kepuasan konsumen menunjukkan bahwa nilai yang signifikan antara harga dengan kepuasan kosnumen. Maka dapat disimpulkan bahwa harga memiliki pengaruh yang besar terhadap kepuasan konsumen pengguna aplikasi Ruangguru, sehingga hipotesis diterima. Hasil penelitian ini didukung oleh penelitian sebelumnya yang dilakukan oleh Rahmawati (2019) dimana menunjukkan bahwa harga berpengaruh positif dan signifikan terhadap kepuasan konsumen pada CV. Larissa Ready Mix Di Kabupaten Pati. Penelitian lain dari Palma \& Andjarwati (2016) yang menunjukkan bahwa terdapat pengaruh yang siginifikan dari harga terhadap kepuasan pada konsumen produk fashion melalui toko online di Surabaya. 


\section{Pengaruh Harga terhadap Loyalitas Konsumen Aplikasi Ruangguru}

Hasil penelitian ini menunjukkan bahwa positif tidak signifikan. Maka dapat disimpulkan bahwa harga tidak berpengaruh besar terhadap loyalitas konsumen. Maknanya adalah konsumen belum loyal meskipun harga yang diberikan Ruangguru sudah baik. Hasil penelitian ini didukung oleh penelitian sebelumnya yang dilakukan oleh Sola (2017) dimana menunjukkan bahwa harga tidak berpengaruh signifikan terhadap loyalitas konsumen pada Sakola Factory Outlet Jogja. Kondisi ini bertolak belakang dengan penelitian sebelumnya. Penelitian lain dari Rahmawati (2019) yang menunjukkan bahwa harga berpengaruh positif dan signifikan terhadap loyalitas konsumen pada CV. Larissa Ready Mix Di Kabupaten Pati. Namun sejalan dengan penelitian dari Pelealu (2015) yang menunjukkan bahwa variabel harga positif namun tidak signifikan terhadap loyalitas konsumen. Setelah digali lebih dalam ternyata ada beberapa hal yang menyebabkan konsumen tidak loyal terhadap produk Ruangguru meskipun harga yang ditawarkan sudah baik. Ruangguru bukan satu-satunya produk aplikasi berbasis teknologi pendidikan, sudah cukup banyak saat ini produk teknologi pendidikan yang serupa yang menawarkan jasa yang sama dengan harga yang bersaing. Sehingga walaupun harga yang diberikan oleh Ruangguru sudah baik dan bervariasi, yang tentunya juga sudah disesuaikan dengan kemampuan siswa. Namun hal itu tidak menjadi alasan konsumen setia dan loyal berangganan aplikasi Ruangguru.

\section{Pengaruh Personal Selling terhadap Kepuasan Konsumen Aplikasi Ruangguru}

Hasil penelitian ini menunjukkan bahwa nilai yang postif dan signifikan,yaitu sebesar 0,009 lebih kecil dari tingkat alpha 5\% $(0,05)$ dan nilai $\mathrm{T}$ statistik sebesar 2,634 lebih besar dari 1,98761 (t-tabel). Maka dapat disimpulkan bahwa personal selling berpengaruh positif signifikan terhadap kepuasan konsumen Ruangguru. Artinya adalah personal selling memiliki pengaruh yang besar terhadap kepuasan konsumen pengguna aplikasi Ruangguru. Makna temuan ini adalah pelanggan merasa puas atas personal selling yang baik. Kondisi ini mendukung penelitian dari Rizan \& Anjarestu (2013) menyatakan bahwa personal selling berpengaruh signifikan terhadap kepuasan konsumen pada pelanggan majalah info Bekasi, serta Sukri (2020) yang menyatakan bahwa personal selling berpengaruh signifikan terhadap kepuasan konsumen produk Semen Padang.

\section{Pengaruh Personal Selling terhadap Loyalitas Konsumen Aplikasi Ruangguru}

Hipotesis keenam, berdasarkan hasil penelitian menunjukkan bahwa nilai negatif dan tidak signifikan, dimana dengan nilai T Statistik 2,506 lebih besar dari 1,98761 (t-tabel). Nilai signifikan sebesar 0,013 nilai lebih kecil dari tingkat alpha 0.05. Dalam hal ini, pengaruh personal selling terhadap loyalitas konsumen pengguna aplikasi Ruangguru, tidak diterima. Hal ini menunjukkan bahwa personal selling yang dari aplikasi Ruangguru tidak mempengaruhi dalam hal loyalitas konsumen. Hasil temuan ini sejalan dengan penelitian sebelumnya yang dilakukan oleh Pelealu (2015) yang menunjukkan bahwa variabel personal selling berpengaruh negatif dan tidak signifikan terhadap loyalitas konsumen. Namun berbeda halnya dengan penelitian lain dari Purwati et al., (2020) yang menunjukkan bahwa Personal selling berpengaruh signifikan terhadap loyalitas konsumen pada PT. WanRiau IndoXP Pekanbaru. Artinya adalah personal selling belum tentu memiliki pengaruh terhadap loyalitas konsumen. Sehingga maknanya adalah konsumen belum tentu loyal walaupun personal selling dari aplikasi Ruangguru sudah baik. Walaupun demikia, kualitas personal selling tetap harus ditingkatkan mengingat sebagai produk jasa konsumen tetap memperhatikan hal tersebut. 


\section{Pengaruh E-WOM terhadap Kepuasan Konsumen Aplikasi Ruangguru}

Hipotesis ketujuh pada penelitian ini adalah terdapatnya pengaruh antara E-WOM terhadap kepuasan konsumen. Berdasarkan perhitungan yang telah dilakukan didapatkan bahwa menunjukkan nilai parameter yang positif 0,115 . Nilai tidak signifikan,yaitu sebesar 0,113 lebih besar dari tingkat alpha 5\% $(0,05)$ dan nilai T statistik sebesar 1,586 lebih kecil dari 1,98761 (t-tabel). Maka dapat disimpulkan bahwa E-WOM ternyata positif namun tidak signifikan terhadap kepuasan konsumen Ruangguru. Sehingga hipotesis tidak diterima. Hasil temuan ini didukung oleh temuan sebelumnya dari Safitri (2019) bahwa tidak ada pengaruh yang signifikan antara Electronic Word of Mouth terhadap kepuasan konsumen pada warung Upnormal. Hal ini menunjukkan bahwa E-WOM tidak mempengaruhi dalam hal kepuasan konsumen. Namun hasil temuan ini berbeda dengan penelitian sebelumnya yang dilakukan oleh Yuliasari (2020) dimana menyatakan bahwa Electronic Word of Mouth (E-WOM) berpengaruh positif dan signifikan terhadap kepuasan nasabah dalam menggunakan mobile banking. di BSM KCP Boyolali. Sama halnya dari penelitian sebelumnya oleh Emizola (2018) yang menyatakan bahwa E-WOM berpengaruh positif dan signifikan terhadap kepuasan konsumen. Artinya adalah E-WOM belum tentu menjadi pengaruh besar terhadap kepuasan konsumen.

\section{Pengaruh E-WOM terhadap Loyalitas Konsumen Aplikasi Ruangguru}

Terdapatnya pengaruh anatara E-WOM terhadap loyalitas konsumen. Berdasarkan hasil penelitian didapatkan bahwa pengaruh antara E-WOM dengan loyalitas konsumen menunjukkan nilai parameter yang positif dengan nilai yang signifikan,yaitu sebesar 0,000 lebih kecil dari tingkat alpha 5\% (0,05) dan nilai T statistik sebesar 4,531 lebih besar dari 1,98761 (t-tabel). Kondisi ini menunjukkan bahwa E-WOM memiliki pengaruh yang besar terhadap loyalitas konsumen pengguna aplikasi Ruangguru, sehingga hipotesis diterima. Adapun makna temuan ini adalah konsumen akan loyal terhadap aplikasi Ruangguru jika ia mendapatkan ada proses penerimaan E-WOM yang baik. Hasil penelitian ini didukung oleh penelitian sebelumnya yang dilakukan oleh Yuliasari (2020) yang menyatakan bahwa E-WOM berpengaruh positif dan signifikan terhadap loyalitas nasabah dalam menggunakan mobile banking di BSM KCP Boyolali. Begitu juga dalam penelitian lain dari Purwanda \& Wati (2018) yang menyatakan bahwa variabel E-WOM berpengaruh positif signifikan terhadap variabel loyalitas pelanggan secara parsial. Jadi semakin baik electronic word of mouth maka semakin tinggi loyalitas.

\section{Pengaruh Kepuasan Konsumen terhadap Loyalitas Konsumen Aplikasi Ruangguru}

Berdasarkan hasil penelitian menunjukkan nilai parameter yang positif dengan nilai yang signifikan. Hal ini menunjukkan bahwa kepuasan konsumen ternyata akan mempengaruhinya dalam pengimplementasian loyalitas konsumen Ruangguru. Makna temuan ini adalah bahwa konsumen akan melanjutkan berlangganan kembali dikemudian hari, akan tetap menggunakan aplikasi belajar Ruangguru meskipun terdapat fasilitas yang sama yang ditawarkan oleh aplikasi belajar lain, dan akan akan merekomendasikan kepada orang lain untuk berlangganan aplikasi belajar Ruangguru. Hasil ini juga didukung oleh penelitian sebelumnya dari Haghighi (2012) kepuasan konsumen berpengaruh signifikan terhadap loyalitas pada industri restoran, begitu juga penelitian dari Osman \& Sentosa (2013) bahwa kepuasan konsumen berpengaruh signifikan terhadap loyalitas pada wisata pedesaan malaysia. Beberapa faktor pendukung menyebabkan konsumen loyal adalah diantaranya puas terhadap harga, fasilitas/fitur belajar, puas karena manfaat yang didapatkan, pelayanan customer service, kemudahan mendapatkan informasi, 
terhadap kesopanan dan keramahan sales consultant/penjual produk, reputasi produk baik. Jadi semakin baik kepuasan konsumen maka semakin tinggi loyalitas.

\section{Kepuasan Konsumen Memediasi Pengaruh Kualitas Produk Terhadap Loyalitas}

Berdasarkan hasil penelitian yang ditemukan bahwa variabel kualitas produk terhadap loyalitas konsumen Ruangguru melalui kepuasan konsumen sebagai mediasi bernilai positif namun tidak signifikan. Artinya bahwa, variabel kepuasan konsumen tidak mampu berperan dalam memediasi pengaruh antara variabel kepuasan konsumen dengan loyalitas konsumen Ruangguru. Sehingga hal ini menunjukkan kualitas produk terhadap loyalitas yang dimediasi kepuasan kosnumen hipotesis di tolak. Artinya bahwa variabel kepuasan tidak mampu memperkuat hubungan antara variabel kualitas produk terhadap loyalitas konsumen. Namun hasil penelitian ini berbanding terbalik dengan penelitian yang dilakukan oleh Rahmawati \& purnama (2019) yang menyatakan bahwa kualitas produk terhadap loyalits pelanggan melalui kepuasan sebagai variabel intervening terdapat pengaruh positif dan signifikan. Begitu juga penelitian dari Hamsinah et al., (2019) bahwa Hal ini menunjukkan bahwa variabel kepuasan mampu memperkuat hubungan antara variabel kualitas produk terhadap loyalitas konsumen pada pelanggan coffe. Hal ini mengindikasikan bahwa Ruangguru dalam segi kualitas produk belum memenuhi ekspektasi kepuasan konsumen, sebab bisa saja jika konsumen sudah puas akan kualitas produk maka bisa saja Ruangguru memiliki loyalitas yang baik.

\section{Kepuasan Konsumen Memediasi Pengaruh Harga Terhadap Loyalitas Konsumen}

Berdasarkan hasil penelitian menunjukkan nilai parameter yang positif dengan nilai yang signifikan. Dimana variabel harga terhadap loyalitas konsumen Ruangguru melalui kepuasan konsumen sebesar 0,278, dimana dengan nilai T Statistik 4,035 lebih besar dari 1,98761 (t-tabel). Nilai p-value sebesar 0,000 nilai ini lebih kecil dari tingkat alpha 0.05. Jadi dapat disimpulkan bahwa, variabel kepuasan konsumen dapat memediasi harga terhadap loyalitas konsumen Ruangguru. Dengan kata lain, variabel kepuasan konsumen mampu berperan baik dalam memediasi pengaruh antara variabel harga dengan loyalitas konsumen Ruangguru. Artinya hipotesis diterima. Dalam hal ini dapat diartikan bahwa konsumen merasa puas dan akan melanjutkan berlangganan kembali dikemudian hari, dan akan tetap menggunakan aplikasi belajar Ruangguru. Hasil ini juga mendukung penelitian sebelumnya dari Rahmawati (2019) yang menemukan bahwa harga berpengaruh positif dan signifikan terhadap kepuasan konsumen dan loyalitas konsumen Pada CV. Larissa Ready Mix Di Kabupaten Pati.

\section{Kepuasan Konsumen Memediasi Pengaruh Personal Selling Terhadap Loyalitas}

Terdapat pengaruh antara variabel personal selling terhadap loyalitas konsumen Ruangguru melalui kepuasan konsumen sebesar 0,080, dimana dengan nilai T Statistik 2,506 lebih besar dari 1,98761 (t-tabel). Nilai signifikan sebesar 0,013 nilai ini lebih kecil dari tingkat alpha 0.05. Jadi dapat disimpulkan bahwa, variabel kepuasan konsumen merupakan variabel mediasi. Dengan kata lain, variabel kepuasan konsumen mampu berperan baik dalam memediasi pengaruh antara personal selling dengan loyalitas konsumen Ruangguru. variabel kepuasan mampu memperkuat hubungan antara variabel personal selling terhadap loyalitas konsumen. Artinya hipotesis diterima. Berdasarkan hal ini dapat diartikan bahwa kualitas produk tentu memiliki pengaruh terhadap loyalitas konsumen. Makna temuan ini adalah konsumen akan loyal terhadap aplikasi Ruangguru jika ia mendapatkan kepuasan yang baik dari layanan personal selling. Berdasarkan teori dari Menurut Terence (2010) personal selling adalah suatu bentuk 
komunikasi orang perorangan dimana seseorang wiraniaga berhubungan dengan calon pembeli dan berusaha mempengaruhi agar mereka membeli produk atau jasanya.

Kepuasan Konsumen Memediasi Pengaruh E-WOM Terhadap Loyalitas Konsumen

Berdasarkan hasil penelitian menyatakan bahwa kepuasan konsumen tidak mampu berperan dalam memediasi Electronic Word of Mouth (E-WOM) terhadap loyalitas konsumen. Sehingga dapat disimpulkan bahwa hipotesis yang menyatakan pengaruh EWOM terhadap loyalitas yang dimediasi oleh kepuasan ditolak. Artinya adalah bahwa variabel kepuasan tidak mampu memperkuat hubungan antara variabel E-WOM terhadap loyalitas konsumen. Hal ini mengindikasikan bahwa aplikasi Ruangguru belum memiliki kesan E-WOM yang cukup baik. Hasil penelitian ini sejalan dengan penelitian yang dilakukan oleh Herdiyani (2015) yang menunjukkan bahwa Electronic Word of Mouth tidak berpengaruh signifikan terhadap loyalitas pelanggan yang dimediasi kepuasan konsumen. Namun hasil ini berbeda dengan hasil penelitian dari Yuliasari (2020) yang menyatakan bahwa Kepuasan dapat memediasi antara pengaruh Electronic Word of Mouth (EWOM) terhadap loyalitas nasabah, artinya terdapat hubungan yang bermakna antara EWOM dengan loyalitas dimana dimediasi oleh kepuasan konsumen.

\section{SIMPULAN DAN SARAN}

\section{Simpulan}

1. Hasil penelitian menunjukkan bahwa variabel kualitas produk berpengaruh tidak signifikan terhadap kepuasan konsumen juga terhadap loyalitas konsumen, variabel harga berpengaruh signifikan terhadap kepuasan konsumen namun terhadap loyalitas konsumen berpengaruh tidak signifikan, sedangkan variabel personal selling berpengaruh signifikan terhadap kepuasan konsumen namun terhadap loyalitas konsumen tidak signifikan, variabel E-WOM berpengaruh tidak sigifikan terhadap kepuasan konsumen dan loyalitas konsumen, sedangkan variabel mediasi kepuasan konsumen berpengaruh signifikan terhadap loyalitas.

2. Masing-masing dari variabel kualitas produk dan E-WOM berpengaruh tidak signifikan terhadap loyalitas konsumen melalui kepuasan konsumen sebagai variabel mediasi. Selain itu, masing-masing dari varaibel harga dan personal selling berpengaruh signifikan terhadap loyalitas konsumen melalui kepuasan konsumen sebagai variabel mediasi.

3. Hanya variabel harga dan personal selling yang dapat mempengaruhi kepuasan maupun loyalitas konsumen.

\section{Saran}

Variabel yang digunakan dalam penelitian ini beberapa terbukti tidak mempengaruhi satu sama lain, diharapkan dipenelitian selanjutnya dapat mencoba dengan mengganti variabel yang tidak mempengaruhi menggunakan variabel lain. seperti citra merek, promosi penjualan dan lain sebagainya, dikarenakan diindikasi kemungkinan memiliki pengaruh. Hal ini dimaksudkan agar memperoleh hasil yang lebih baik. Terdapat dua variabel yang bernilai positif signifikan terhadap kepuasan konsumen yaitu variabel harga dan personal selling, hal ini diharapkan Ruangguru tetap mempertahankan kualitas harga dan personal selling nya karena kedua hal ini yang cukup dekat dan erat dengan konsumen.

\section{DAFTAR PUSTAKA}

Assauri, S. (2011). Manajemen Pemasaran Dasar Konsep dan Strategi. In PT Raja Grafindo Persada, Jakarta. 
Atmawati, R., dan Wahyuddin, M. (2004). Analisis Pengaruh Kualitas Pelayanan Terhadap Kepuasan Konsumen Pada Matahari Departement Store Di Solo Grand Mall. Jurnal Ekonomi Manajemen Sumber Daya.

Chantya, A., And Sunaryo. (2015). The Effect Of Advertising, Personal Selling, And Sales Promotion To Purchase Decision Of Prudential Individual Customers.

Ferdinand, A. (2011). Metode Penelitian Manajemen Pedoman Penelitian untuk Penulisan Skripsi Tesis dan disertai Ilmu Manajemen. In Semarang: Universitas Diponegoro.

Ghozali, I. 2008. SEM Metode Alternatif dengan PLS. In Semarang: Badan Penerbit Universitas Diponegoro.

Hamid, R. S., and Anwar, D. S. M. (2019). Structural Equation Modeling (SEM) Konsep dasar dan aplikasi program smart PLS 3.2.8 dalam riset bisnis. In Structural Equation Modeling.

Hamsinah, Sjahrudin, H., \& Gani, M. (2019). Jurnal organisasi dan manajemen. Jurnal Organisasi Dan Manajemen, 10(1), 15-26.

Hennig-Thurau, T., Gwinner, K. P., Walsh, G., \& Gremler, D. D. (2004). Electronic wordof-mouth via consumer-opinion platforms: What motivates consumers to articulate themselves on the Internet? Journal of Interactive Marketing, 18(1).

Haghighi, M. (2012). Evaluation of factors affecting customer loyalty in the restaurant industry. African Journal of Business Management, 6(14), 5039-5046.

Hasan, Ali. 2010. Marketing Dari Mulut Ke Mulut, Cetakan 1. Yogyakarta: Media Pressindo.

Hurriyati, R. (2005). Bauran Pemasaran dan Loyalitas Konsumen. Alfabeta Bandung.

Indoxp, P. T. W., Purwati, A. A., Rukmana, K., \& Deli, M. M. (2020). the Effect of Personal Selling and Service Quality on Customer Loyalty At. Journal of Applied Business and Technology ( JABT ), 1, 1-7.

Johannes, Raf, M., \& Lukman, M. (2009). Analisis Kepuasan Nasabah Prioritas Berdasarkan Bauran Pemasaran (Kasus Pada PT. Bank Central Asia, Tbk Kantor Cabang Utama Jambi). Jurnal Manajemen Pemasaran Modern. Vol. 1 No.1.

Kotler, P, Philip, \& Armstrong. (2008). PrinsipPrinsip Pemasaran. Edisi ketigabelas. Alih Bahasa oleh David Octarevia. Jakarta : Salemba Empat.

Kotler, P. \& Armstrong, G. (2011). Lokasi, Harga, Dan Kualitas Pelayanan. In Jurnal.

Kotler, P., \& Armstrong, G. (2012). Principles of Marketing Global. In USE: Pearson Education.

Kotler, P., \& Keller, K. (2013). Analisis Pengaruh Implementasi Manajemen Kualitas. Studi Manajemen Dan Organisasi.

Kotler, P., \& Keller, K. (2013). Manajemen Pemasaran Jilid 2. In Penerbit Erlangga.

Kotler, P., \& Armstrong, G. (2013). Prinsip-Prinsip Pemasaran Jilid I. In Erlangga.

Kotler, P., \& Keller, K. (2017). Manajemen Pemasaran, Edisi 12, Jilid 1, PT.Indeks,. Jakarta. In $e$-Jurnal Riset Manajemen.

Natarajan, R., \& Sudha, V. (2016). A Relationship Between Brand Image and Brand Loyalty. International Journal of Economic and Business Review, 4(5), 139-145.

Nelwan, O., \& Mandey, S. (2014). Customer Relationship Management (Crm) Dan Personal Selling Pengaruhnya Terhadap Kepuasan Konsumen Pada Pt Virgo Ekspres Tours \& Travel Manado. Jurnal Riset Ekonomi, Manajemen, Bisnis Dan Akuntansi, 2(1), 99-110.

Osman, Z., \&Sentosa, I. (2013). Influence of customer satisfaction on service quality and trust relationship in Malaysian rural tourism / Zahir Osman and Ilham Sentosa. Business \& Management Quaterly Review, 4(2), 12-25. 
Palma, M. A., \& Andjarwati, A. L. (2016). Pengaruh Kualitas Produk, Kemudahan, Dan Harga Terhadap Niat Beli Ulang Dengan Kepuasan Sebagai Variabel Intervening (Studi Pada Pelanggan Produk Fashion Melalui Toko online di Surabaya). Jurnal Riset Ekonomi Dan Manajemen, 16(1), 84.

Pelealu,Y. A. (2015). Analisis Pengaruh Harga Kompetitif, Personal Selling Dan Merchandising Terhadap Loyalitas Pelanggan.

Purnama, A. (2019). Analisis Pengaruh Kualitas Produk dan Citra Merek Pada Loyalitas Pelanggan Melalui Kepuasan Pelanggan Sebagai Variabel Intervening (Studi Pada Produk Graphic Processing Unit AMD Radeon). Semarang, Universitas Diponogoro, 29.

Purwanda, E., \& Wati, T. (2018). Pengaruh Electronic Word Of Mouth, Kepercayaan Dan Kepuasan Terhadap Loyalitas Pelangga(Survey Pada Pelanggan Lazada Di Wilayah Bandung Timur). Jurnal INTEKNA, 18(2), 86-91.

Purwati, A. A., Rukmana, K., and Deli, M. M. 2020. The Effect Of Personal Selling And Service Quality On Customer Loyalty At. Journal Of Applied Business And Technology (Jabt), 1 .

Putri, S. W., Rodhiyah, \& Nugraha, H. S. (2015). Diponegoro Journal Of Social And Political Science Tahun 2015, Hal 1-8.

Rahmawati, N. (2019). Pengaruh Persepsi Kualitas Pelayanan, Harga, Dan Kualitas Produk Terhadap Loyalitas Konsumen Dengan Kepuasan Konsumen Sebagai Variabel Intervening. 1-153.

Rizan, M., \& Anjarestu, Y. (2013). Pengaruh Kualitas Produk Dan Personal Selling Terhadap Kepuasan Pelanggan Pada Majalah Info Bekasi (Studi Kasus Pt. Sibk). Jurnal Riset Manajemen Sains Indonesia, 4(1), 78-81.

Safitri, A. (2019). Electronic Word Of Mouth, Kualitas Pelayanan Serta Suasana Kafe Dan Pengaruhnya Terhadap Pembelian Ulang Yang Dimediasi Oleh Kepuasan Konsumen Pada Warunk Upnormal.

Sebayang, S., \& Sembiring, J. (2017). Pengaruh self esteem dan self efficacy terhadap kinerja karyawan studi kasus di PT.Finnet Indonesia, Jurnal Manajemen, Vol.4, No.1, hlm.335.

Shimp, T. A. 2010. Integrated Marketing Comunication In Advertising And Promotion 8e.

Soun-Western : Cengage Learning.

Sukri, S. C. (2020). Pengaruh Advertising, Personal Selling dan Sales Promotion Terhadap Keputusan Pembelian Produk Semen Padang di Kota Medan.

Sumarwan, U. (2003). Perilaku Konsumen: Teori dan penerapannya dalam Pemasaran. Ghalia Indonesia, Jakarta.

Wijayanto, A. (2013). Analisis Faktor-Faktor Yang Memengaruhi Loyalitas Konsumen Tupperware (Studi Pada Konsumen Tupperware Di Universitas Diponegoro). Jurnal Administrasi Bisnis, 2(1), 89-97.

Williamson, O. E. (1999). Strategy research: Governance and competence perspectives. Strategic Management Journal. 